\title{
Biological efficiency of Agaricus brasiliensis cultivated in compost with nitrogen concentrations
}

\author{
Félix G de Siqueira ${ }^{1}$; Emerson T Martos²; Evânia Geralda da Silva ${ }^{2}$; Romildo da Silva ${ }^{2}$; Eustáquio S \\ $\operatorname{Dias}^{2}$ \\ ${ }^{1}$ UnB-Depto Biologia Celular, 70910-900 Brasília-DF, ogatofelix@gmail.com; 2UFLA-Depto Biologia, C. Postal 3037, 37200-000 \\ Lavras-MG, etmartos@gmail.com; evaniasilva10@hotmail.com; romsilva@ufla.br; esdias@ufla.br
}

\begin{abstract}
The production of compost is one of the most important steps for the cultivation of any species of mushroom. For the Agaricus species, this step is even more complex because it depends on the performance of different microorganisms that act on the substrate, turning it into selective compost that promotes the growth of the fungus to be cultivated. Among the various factors that affect the microbial activity, the initial concentration of nitrogen is considered one of the most important. Due to the lack of conclusive studies about that, the aim of this study was to evaluate the productivity and biological efficiency of Agaricus brasiliensis in compost prepared with different initial concentrations of nitrogen, according to the composting methodology and to the conventional pasteurization techniques (phase I and II). Three initial nitrogen concentrations $(\mathrm{w} / \mathrm{w})\left(\mathrm{T}_{1}=1.0 \% ; \mathrm{T}_{2}=1.5 \%\right.$; and $\left.\mathrm{T}_{3}=2.0 \%\right)$ were tested and mycelial growth was determined in terms of $\mathrm{mm} /$ day for all treatments. The productivity and biological efficiency were also determined. The most efficient initial concentrations of nitrogen were of $1.0 \%$ and $1.5 \%$. This concentration of $\mathrm{N}$ in the compost permitted a faster development of the mushroom with higher productivity when compared to the results obtained with the application of $2 \%$ of nitrogen.
\end{abstract}

Keywords: composting, mushroom cultivation, ammonia, nitrogen concentration.

\section{RESUMO}

Eficiência biológica de Agaricus brasiliensis em composto com concentrações de nitrogênio

A produção do composto é uma das etapas mais importantes para o cultivo de qualquer espécie de cogumelo. Para as espécies Agaricus, essa etapa é ainda mais complexa, porque depende da atuação de diferentes microrganismos que atuam sobre o substrato, transformando-o em um composto seletivo que favorece o crescimento do fungo a ser cultivado. Dentre os diversos fatores que afetam essa atividade microbiana, a concentração inicial de nitrogênio é considerada uma das mais importantes. Em função da falta de estudos conclusivos a respeito, este trabalho teve por objetivo avaliar a produtividade e eficiência biológica de Agaricus brasiliensis em composto preparado com diferentes teores iniciais de nitrogênio, fazendo uso da metodologia de compostagem e pasteurização convencional (fase I e II). Foram testadas três concentrações de nitrogênio iniciais $(\mathrm{w} / \mathrm{w})\left(\mathrm{T}_{1}=\right.$ $1,0 \% ; \mathrm{T}_{2}=1,5 \% \mathrm{e} \mathrm{T}_{3}=2,0 \%$ ) e foi determinado o crescimento micelial em $\mathrm{mm}$ /dia para todos os tratamentos, assim como a produtividade e eficiência biológica. As melhores concentrações iniciais de nitrogênio na metodologia convencional de compostagem foram os teores de $1,0 \%$ e $1,5 \%$. Nessas concentrações de nitrogênio o desenvolvimento do cogumelo foi mais rápida, assim como a sua produtividade em comparação àquela obtida no composto com $2 \%$ de nitrogênio.

Palavras-chave: compostagem, cultivo de cogumelos, amônia, concentração de nitrogênio.

(Recebido para publicação em 22 de outubro de 2009; aceito em 17 de março de 2011)

(Received on October 22, 2009; accepted on March 17, 2011)

The cultivation of Agaricus brasiliensis mushroom is based on a technology which was adapted from the cultivation of Agaricus bisporus (button mushroom) due to the fact that both mushrooms show a similar behavior (Dias, 2010). However, the development of an appropriate technology for the cultivation of $A$. brasiliensis is essential to increase their productivity.

Composting is a necessary process to obtain a selective and appropriate substrate for the cultivation of mushrooms that belong to the genus Agaricus (Chang \& Miles, 2004; Sánchez, 2004). Within the process, the materials are subjected to the natural action of several different microorganisms. During the process, soluble sugars are degraded and the temperature increases. It favors the development of thermophilic microorganisms, resulting into the generation of selective compost for the mushroom (Ross \& Harris, 1983; Stölzer \& Grabble, 1991).

The initial level of nitrogen in the substrate is one of the most important conditions for the development of this microbiota. Substrates that are very poor in nitrogen do not allow the process to develop itself in an appropriate way. For example, in substrates lacking an adequate carbon/nitrogen ratio $(\mathrm{C} / \mathrm{N}$ ratio), a lower increase is noticed in the substrate temperature. For the Agaricus mushrooms in general, an initial nitrogen concentration $\left(\mathrm{N}_{\text {initial }}\right)$ of approximately $1.5 \%$ is considered normal (Chang \& Miles, 2004). In addition, there is evidence that the final concentration of nitrogen tends to stabilize around $2 \%$, both when using an initial concentration of nitrogen of $1.3 \%$ or when using an initial concentration of 2.5\% (Van Griensven, 1988; Oei, 2003). However, when the initial concentration of nitrogen is high, there is a more intense production of ammonia, depending on the degradation of protein. As a result, it is necessary to extend the process to reduce the 
concentration of ammonia to safe levels for the mycelial growth (Flegg et al., 1985; Fletcher \& Gaze, 2008)

For the cultivation of $A$. bisporus, the conditioning period of the compost in phase II takes 5 to 6 days, sufficient time so that the compost is free of ammonia in excess, detrimental to the growth of fungus. However, in Brazil, it is common to extend the phase II for 8 to 14 days for the cultivation of $A$. brasiliensis (Eira, 2003). It is not known whether $A$. brasiliensis is more sensitive than A. bisporus or if the conditions used in Brazil are less efficient in the elimination of ammonia. Therefore, the study of factors influencing the process, can contribute to the establishment of an appropriate technology for $A$. brasiliensis and to Brazilian conditions.

Considering that the quality of the final compost depends on the microbial succession during composting, which depends on the $\mathrm{N}_{\text {initial }}$, we evaluated the effect of the compost produced with different initial nitrogen concentration on the productivity of the $A$. brasiliensis mushroom.

\section{MATERIAL AND METHODS}

Two experiments were carried out in Lavras to assess the effect of initial concentration of nitrogen on mycelial growth and biological efficiency of $A$. brasiliensis and evaluate three concentrations of nitrogen. The experimental design was completely randomized with 10 replicates of each compost/nitrogen concentration and 6 replicates for centesimal analysis of each nitrogen concentration treatment. The same composts were used in both experiments, however, for the experiment to evaluate the mycelial growth we used bags with only $1 \mathrm{~kg}$ of compost, while for the experiment of biological efficiency we used pots with a capacity of $5 \mathrm{~kg}$ of compost.

For the experiment of biological efficiency, the cultivation of the mushroom A. brasiliensis was conducted under the conditions used by most producers in Brazil, which is, with partial control of temperature and humidity, taking advantage of the warmer months of the year, falling between August and April.

For both experiments, in addition to producing the compost according the treatments, it was necessary to obtain the mushroom spawn, which was prepared during the same period of production of the mushroom compost.

The spawn was prepared with rice husk enriched with $10 \%$ wheat bran (w/w). The rice husk was pre-cooked for 30 minutes, drained to eliminate excess of water and set aside. The wheat bran was moistened apart to reach a humidity level of about $65 \%$ and autoclaved for 30 minutes. The previously cooked rice husk was then added to the autoclaved wheat bran, and the mixture was kept in glass flasks (300 g of substrate/ flask), covered with cotton balls and autoclaved at $121^{\circ} \mathrm{C}$ for 1 hour. The autoclaving process was repeated under the same conditions after 24 hours. The inoculation took place in a laminar flow chamber, using five 6-mm discs of the culture media (BDA) colonized with Agaricus brasiliensis CS1, followed by incubation at room temperature, which ranged from 20 to $28^{\circ} \mathrm{C}$.

The compost was prepared from sugarcane bagasse (Saccharum officinarum (L.)) (135 kg), Coastcross hay (Cynodon dactylon (L.) Pers) (135 kg), wheat bran (30 $\mathrm{kg})$, and supplemented with simple superphosphate $(3 \mathrm{~kg})$, limestone (6 $\mathrm{kg})$, gypsum (6 kg) and urea. The quantity of urea varied from one treatment to the other, in order to reach the pre-determined initial nitrogen concentrations $(\mathrm{w} / \mathrm{w})$, i.e., $\mathrm{T}_{1}(1.0 \% \mathrm{~N})$ $1.0 \mathrm{~kg} ; \mathrm{T}_{2}(1.5 \% \mathrm{~N})=4.4 \mathrm{~kg}$; and $\mathrm{T}_{3}$ $(2.0 \% \mathrm{~N})=6.7 \mathrm{~kg}$. All raw materials for chemical analysis were first dried at $65^{\circ} \mathrm{C}$, for 48 hours, before being weighed. The total nitrogen content of the raw materials was determined by the Kjeldahl method (AOAC, 1990).

The Coast-cross hay was first immersed in water for a few minutes. The wetted hay and crushed sugarcane bagasse were layered in a wooden frame $(1.2 \times 1.2 \times 1.2 \mathrm{~m})$, in order to get a more homogeneous mixture due to the possibility of turning it over several successive times. During the initial layering, the materials were watered until there was run-off water coming out of the mixture. During the phase I, the compost was regularly turned over for 2 weeks on Mondays, Wednesdays and Fridays, and the humidity level was corrected to $65 \%$ when necessary. The humidity level was evaluated by manually squeezing the substrate and looking for water droplets to appear. During the fourth turn, the wheat bran, limestone, gypsum, superphosphate and urea were mixed into the substrate, after verifying that the substrate was sufficiently moistened. After that, starting phase II, the compost was pasteurized at $60^{\circ} \mathrm{C}$ for 12 hours into the tunnel, and kept under temperatures ranging from 40 to $45^{\circ} \mathrm{C}$, for 13 days, ending the phase II. During this phase, the compost was not turned over, but the ventilation system provided constant aeration of the material, in order to avoid anaerobic conditions. After this period, the ventilation system was turned off, leaving the compost to rest with the door open until the temperature dropped below $30^{\circ} \mathrm{C}$.

The total nitrogen (N-total) concentrations of the raw materials and of the composts after phase II were determined according to the Kjeldahl method, after the extraction of the liquid, obtained through pressing the compost samples (approximately 1.5 $\mathrm{kg}$ ) before and after pasteurization. The ammonium content was determined in triplicate as described by Kiehl (1985). In order to perform the extraction of the liquid, the samples were placed under a 5 ton hydraulic press, which extracted approximately $300 \mathrm{~mL}$ of liquid from each sample.

For the experiment to evaluate the mycelial growth, polypropylene bags containing $1 \mathrm{~kg}$ of compost (10 repetitions) were inoculated with $5 \mathrm{~g}$ of spawn, deposited on top of the compost. The bags were protected with filter paper to allow gaseous exchange and avoid external contamination and were incubated under the same conditions described above. The mycelial growth was measured on the $10^{\text {th }}, 20^{\text {th. }}$ and $30^{\text {th }}$ days after inoculation, and the measurements were converted to $\mathrm{mm} /$ day.

To evaluate the biological efficiency, the compost was transferred to plastic 
bags $(10 \mathrm{~kg} / \mathrm{bag})$ and inoculated with $200 \mathrm{~g}$ of spawn, produced as described above. The bags were loosely closed to allow respiration, and were incubated on shelves at room temperature (at a minimum temperature of $8^{\circ} \mathrm{C}$ during the night and a maximum temperature of $26^{\circ} \mathrm{C}$ during the day).

After complete colonization, the compost was transferred to $14 \mathrm{~L}$ polyethylene pots (5 $\mathrm{kg}$ compost/pot) and covered with $5 \mathrm{~cm}$ of damp casing material. Rhodic Hapludox soil, horizon B, was sieved (mesh size $1 \mathrm{~cm}$ ) to remove roots, stones and vegetation, being used as the casing. The soil was mixed with ground charcoal from Eucalyptus in the proportion of $4: 1$ (v:v) (soil:charcoal). The mixture had its $\mathrm{pH}$ adjusted to 7.0 by the addition of limestone, in accordance with the previous soil analysis. After casing, the casing layer was wet to saturation, but not over-soaked. Moderate watering, twice a week, kept the casing layer humid until the end of the cultivation.

The pots described above were transferred to the mushroom house. The floor was kept wet during the day to keep the humidity above $80 \%$. The internal temperature varied naturally according to environmental conditions, however, the windows were kept open during the day to favor airflow and to keep the temperature below $30^{\circ} \mathrm{C}$ on warmer days. The temperature inside the house was monitored using a maximum and minimum temperature thermometer, and the air humidity was monitored by a hygrometer.

Mushroom harvesting occurred in the morning and late afternoon, during 101 days. After harvesting the mushrooms, their bases were cleaned using a brush, so that they could be weighed without any soil or charcoal pieces. After determining the fresh mushroom mass, the same were washed, sliced, dried at $55^{\circ} \mathrm{C} \pm 5$ for 24 hours, wrapped in polypropylene bags with a silica sachet and hermetically sealed.

Throughout the harvesting period of mushrooms, samples were taken for determination of centesimal composition of mushrooms produced in compost with different initial nitrogen concentrations. The chemical analysis of the mushrooms was done in triplicate. Before analysis, the mushrooms were dryed at $55^{\circ} \mathrm{C} \pm 5$ for approximately 24 hours, according to the procedures outlined for obtaining the commercial product. After drying process, they were grounded in a mini processor to obtain the necessary granulometry for each kind of analysis, and stored in polyethylene flasks at $4 \pm 2^{\circ} \mathrm{C}$.

According to the procedures of the Adolfo Lutz Institute (1985), we analyzed the mushrooms for moisture, fat, ash and raw fiber content. The protein fraction was determined by the "micro-Kjeldahl" method, and the raw mushroom protein content was determined from its level of nitrogen, using the conversion factor $\mathrm{N} \times 4.38$, according to Miles \& Chang (1997). The total sugars were obtained according to the Somogyi methodology, which was modified by Nelson (1944).

The data were analyzed using the SISVAR-UFLA program (Ferreira, 2000), and the treatment means were compared for statistical significance using the Scott-Knott test at a 5\% probability level (mycelial growth and A. brasiliensis mushroom production) and Tukey test $1 \%$ (chemical analysis).

\section{RESULTS AND DISCUSSION}

All treatments resulted in approximately the same final nitrogen content in the compost, with roughly $2.2 \%$ of dry matter (Table 1 ), despite the differences in the $\mathrm{N}_{\text {initial }}$ for each treatment. According to Oei (2003), the increase in nitrogen in the biomass of the compost is related to the initial $\mathrm{N}$ content. Therefore, a compost with an initial level of nitrogen equal to $1.3 \%$ reaches the $\mathrm{N}$ content of $2.3 \%$ at the end of phase II. A compost with a $\mathrm{N}_{\text {initial }}$ of $2 \%$ tends to maintain the same percentage of $\mathrm{N}$ during composting. On the other hand, a compost with a $\mathrm{N}_{\text {initial }}$ higher than $2.5 \%$ tends to have its $\mathrm{N}$ level decreased to $2 \%$ at the start of phase II (van Griensven, 1988). Thus, a compost with a higher $\mathrm{N}_{\text {initial }}$ produces more ammonia and, therefore, also requires more time for the elimination of ammonia to safe levels for the mycelial growth. On the other hand, a low $\mathrm{N}_{\text {initial }}$ can be correlated with the quality of the microbial activity in the compost, rather than affecting its final nitrogen concentration.

The higher the $\mathrm{N}_{\text {initial }}$ in the compost was, the higher the concentration of $\mathrm{NH}_{4}^{+}$was at the end of the process (Table 1). As expected, the $\mathrm{NH}_{4}^{+}$concentration at the end of phase I was extremely high and was strongly influenced by the $\mathrm{N}_{\text {initial }}$. The $\mathrm{NH}_{4}^{+}$production is the result of the degradation of proteins by microorganisms in the compost and this degradation initially releases $\mathrm{NH}_{3}$, which is mostly volatilized, but some of it reacts with water and is then retained in the compost as $\mathrm{NH}_{4}^{+}$. Thus, a high $\mathrm{NH}_{4}^{+}$value at the end of phase I is not only a common occurrence but even a favorable one, as the nitrogen dissolved in the compost water will be important for the nutrition of the thermophilic microorganisms developed during phase II of composting. On the other hand, it is desirable that at the end of phase II the concentration of $\mathrm{NH}_{4}^{+}$becomes drastically reduced, as this substance is extremely toxic for the mycelial growth of the Agaricus mushrooms (Flegg et al., 1985; Fletcher \& Gaze, 2008). That is the reason why the conditioning of the compost during phase II becomes extremely important, because it is during this process that the thermophilic microorganisms use the ammonia dissolved in compost water as a source of nitrogen for the production of microbial protein.

As a result, at the end of phase II, a reduction of $\mathrm{NH}_{4}^{+}$to levels below the values considered critical for the mycelial growth of the fungus is expected. Composts with a high humidity level may have high free ammonia concentrations, and the Agaricus bisporus mycelium either dies or has its production inhibited by ammonia levels in compost above the limit of human olfactory capability, which is situated between 10 and 20 ppm (Flegg et al., 1985). In practical terms, we consider the end of phase II to be when it is no longer possible to smell ammonia in the compost. However, other authors consider that a limit of $0.03 \%$ ammonia in relation to dry matter marks the end of phase 
Table 1. Concentration of ammonium $\left(\mathrm{NH}_{4}^{+}\right)$at the end of phases I and II and the concentration of total nitrogen $\left(\mathrm{N}_{\text {total }}\right)$ at the end of the composting process for cultivation of Agaricus brasiliensis as a function of the $\mathrm{N}_{\text {initial }}$ in the compost (concentração de $\mathrm{NH}_{4}^{+}$no fim das fases I e II e concentração de nitrogênio total $\left(\mathrm{N}_{\text {total }}\right)$ no final do processo de compostagem para cultivo de Agaricus brasiliensis em função do $\mathrm{N}_{\text {inicial }}$ do composto). Lavras, UFLA, 2007.

\begin{tabular}{|c|c|c|c|c|c|}
\hline \multirow{3}{*}{ N-initial } & \multicolumn{4}{|c|}{$\mathrm{NH}_{4}^{+}$} & \multirow{3}{*}{$\begin{array}{c}\text { N-total } \\
(\%)\end{array}$} \\
\hline & \multicolumn{2}{|c|}{ Phase I } & \multicolumn{2}{|c|}{ Phase II } & \\
\hline & $\%$ & ppm & $\%$ & ppm & \\
\hline $\mathrm{T}_{1}(1.0 \%$ of $\mathrm{N})$ & 0.059 & 590 & 0.004 & 40 & 2.25 \\
\hline $\mathrm{T}_{2}(1.5 \%$ of $\mathrm{N})$ & 0.158 & 1,580 & 0.006 & 60 & 2.22 \\
\hline $\mathrm{T}_{3}(2.0 \%$ of $\mathrm{N})$ & 0.248 & 2,480 & 0.030 & 300 & 2.26 \\
\hline
\end{tabular}

Table 2. Mycelial growth and $A$. brasiliensis mushroom production as a function of the $\mathrm{N}_{\text {inicial }}$ in the compost. Productivity $=[(\mathrm{g}$ of fresh mushroom $/ \mathrm{g}$ of humid substrate $) \times 100]$; Biological Efficiency $(\mathrm{BE})=[(\mathrm{g}$ of fresh mushroom/g of dry substrate $) \times 100]$ (crescimento micelial e produção do cogumelo $A$. brasiliensis em função do $\mathrm{N}_{\text {inicial }}$ no composto. Produtividade $=$ [(g de cogumelos frescos/g de substrato úmido $) \times 100]$; Eficiência Biológica $(\mathrm{EB})=[(\mathrm{g}$ de cogumelos frescos/g de substratos seco) x 100)]. Lavras, UFLA, 2007.

\begin{tabular}{lccccc}
\hline Treatment & $\begin{array}{c}\text { Mycelial } \\
\text { growth } \\
\text { (mm/day) }\end{array}$ & $\begin{array}{c}\text { Productivity } \\
(\%)\end{array}$ & $\begin{array}{c}\text { Biological } \\
\text { efficiency } \\
(\%)\end{array}$ & $\begin{array}{c}\text { Mushrooms/ } \\
\text { vase (n) }\end{array}$ & $\begin{array}{c}\text { Weight/ } \\
\text { mushroom }\end{array}$ \\
\hline $\mathrm{T}_{1}(1.0 \%$ of $\mathrm{N})$ & $6.1 \mathrm{a}$ & $13.28 \mathrm{a}$ & $44.28 \mathrm{a}$ & $22.1 \mathrm{a}$ & $30.1 \mathrm{a}$ \\
$\mathrm{T}_{2}(1.5 \%$ of $\mathrm{N})$ & $5.2 \mathrm{~b}$ & $13.15 \mathrm{a}$ & $43.82 \mathrm{a}$ & $21.6 \mathrm{a}$ & $29.5 \mathrm{a}$ \\
$\mathrm{T}_{3}(2.0 \%$ of $\mathrm{N})$ & $3.8 \mathrm{c}$ & $10.36 \mathrm{~b}$ & $34.52 \mathrm{~b}$ & $19.0 \mathrm{a}$ & $25.4 \mathrm{a}$ \\
\hline
\end{tabular}

Means followed by the same letter in a given column are not statistically different based on the Scott-Knott test at the 5\% probability level (médias seguidas pela mesma letra em uma coluna não são estatisticamente diferentes baseados no teste de Scott-Knott no nível de 5\% de probabilidade).

Table 3. Chemical analysis of $A$. brasiliensis dry mushrooms after cultivation on substrates with different initial nitrogen concentrations (análise química de cogumelos frescos de $A$. brasiliensis cultivados em diferentes substratos com diferentes concentrações de nitrogênio inicial). Lavras, UFLA, 2007.

\begin{tabular}{lccc}
\hline \multirow{2}{*}{ Analysis } & \multicolumn{3}{c}{ Treatments } \\
\cline { 2 - 4 } & $\mathbf{1 \%} \mathbf{N}$ & $\mathbf{1 . 5 \%} \mathbf{~ N}$ & $\mathbf{2 \%} \mathbf{~}$ \\
\hline Humidity & $10.043 \mathrm{a}$ & $9.926 \mathrm{a}$ & $8.523 \mathrm{a}$ \\
Dry matter & $89.956 \mathrm{a}$ & $90.076 \mathrm{a}$ & $91.476 \mathrm{a}$ \\
Protein & $28.333 \mathrm{a}$ & $28.493 \mathrm{a}$ & $29.353 \mathrm{a}$ \\
Fat & $1.655 \mathrm{a}$ & $2.055 \mathrm{a}$ & $2.140 \mathrm{a}$ \\
Ash & $6.711 \mathrm{a}$ & $6.971 \mathrm{a}$ & $6.788 \mathrm{a}$ \\
Fiber & $5.766 \mathrm{~b}$ & $6.345 \mathrm{a}$ & $6.166 \mathrm{a}$ \\
Total sugars & $0.8323 \mathrm{c}$ & $1.0609 \mathrm{~b}$ & $1.6810 \mathrm{a}$ \\
Glucose & $0.5718 \mathrm{c}$ & $0.6717 \mathrm{~b}$ & $0.6914 \mathrm{a}$ \\
Sucrose & $0.2476 \mathrm{c}$ & $0.3698 \mathrm{~b}$ & $0.9402 \mathrm{a}$
\end{tabular}

Values are represented as percentages. Means followed by the same letter in a given line are not statistically different based on the Tukey test at the $1 \%$ probability level (valores são representados em percentagens. As médias seguidas pela mesma letra em uma linha não são estatisticamente diferentes baseados no teste de Tukey no nível de $1 \%$ de probabilidade).

II. This concentration is still detectable by human olfactory capabilities but it is probably not high enough to inhibit the mycelial growth of the fungus. The limit of $0.03 \%$ ammonia is more easily reached than the value of $10 \mathrm{ppm}$ when the traditional composting system is used or when phase I of composting is conducted in bunkers (Sharma et al., 2000).
We found ammonia concentrations above the limit of $10 \mathrm{ppm}$ at the end of phase II in this experiment. It was first detected by the smell of ammonia in the compost and then confirmed through chemical analysis. The analysis showed ammonia values of 40, 60 and $300 \mathrm{ppm}$ for the $\mathrm{N}$-initial treatments of $1 \%, 1.5 \%$ and $2 \%$, respectively (Table 1). However, when these values were converted to percentage of dry material, they led to values of 0.004 and $0.006 \%$ for the $1 \%$ and $1.5 \% \mathrm{~N}_{\text {initial }}$ treatments and equal to $0.03 \%$ for the treatment with $2 \% \mathrm{~N}_{\text {initial }}$. Therefore, for this treatment, the concentration of ammonia was the maximum value considered acceptable for the mushroom cultivation.

Nitrogen loss in the compost depends on the $\mathrm{N}_{\text {initial }}$, which influences the substrate temperature and the production of ammonia. Additionally, high nitrogen concentrations tend to increase the amount of ammonia formation, while a high $\mathrm{C} / \mathrm{N}$ ratio favors the quick absorption of ammonia by the microbiota (Burrows, 1951; Sharma et al., 2000).

The treatment with $1 \% \mathrm{~N}_{\text {initial }}$ resulted in the best mycelial growth at $6.1 \mathrm{~mm} /$ day, followed by the treatment with $1.5 \%$ and $2 \%$, at 5.2 and $3.8 \mathrm{~mm} /$ day, respectively (Table 2). These results are probably related to the ammonia concentration of the compost, as discussed previously.

In the experiment that evaluated productivity and biological efficiency, the treatment with the highest $\mathrm{N}_{\text {initial }}(2 \%)$ resulted only in a partial colonization in two bags and in a complete absence of colonization in three bags, in addition to resulting in the lowest mycelial growth. This mycelial growth result clearly show that the $\mathrm{N}_{\text {initial }}$ of $\%$ may not be ideal for A. brasiliensis mushroom cultivation, at least under the formulation tested in this study.

For the productivity and biological efficiency experiments, A. brasiliensis was cultivated for 101 days after casing. Temperature oscillated from 17 to $28^{\circ} \mathrm{C}$ during this period, with the lowest temperatures occurring at night. The relative humidity of the air oscillated between $75 \%$ and $90 \%$ 
during cultivation. Differences between treatments for number of mushrooms and average mushroom mass were not significant (Table 2), but there was a tendency of reduction in the number of mushrooms, as well as a reduction in mushroom mass, with increasing $\mathrm{N}_{\text {initial }}$, especially at $2 \%$ nitrogen. On the other hand, significant differences in productivity and biological efficiency were observed between different treatments. The best productivity results (13.28\% and $13.15 \%)$ were obtained from $1 \%$ and $1.5 \% \mathrm{~N}$ treatments, respectively, while the treatment with $2 \% \mathrm{~N}$ had the lowest productivity $(10.36 \%)$. These results are contrary to speculations from certain mushroom growers and businesses that the ideal compost nitrogen concentration for the cultivation of Agaricus brasiliensis is 2\%. Andrade et al. (2007) obtained a productivity of approximately $10 \%$ and biological efficiency of $33.63 \%$ in the cultivation of $A$. blaze i in compost (mixture of crushed sugarcane, coastcross grass trash, soybean meal, gypsum, and calcitic limestone) with around $1 \%$ $\mathrm{N}_{\text {initial }}$.

According to Noble \& Gaze (1995), an increase in the $\mathrm{N}_{\text {initial }}$ level from $1.6 \%$ to $3.1 \%$ in compost for Agaricus bisporus cultivation did not result in good productivity. Nitrogen increases in compost resulted in a higher loss of dry material, as well as higher $\mathrm{NH}_{3}$ release. González-Matute \& Rinker (2006) reported that when testing different commercial ammonia suppressants with different levels of $\mathrm{N}_{\text {initial }}$ in compost for Agaricus bisporus cultivation, an $\mathrm{N}_{\text {initial }}$ level of $1.83 \%$ was found to be the ideal concentration for this kind of mushroom.

The yield obtained in this experiment confirmed the mycelial growth results, and showed a direct correlation between productivity and ammonia concentrations in the compost. The treatment with $1 \%$ and $1.5 \% \mathrm{~N}_{\text {initial }}$ resulted in the highest mycelial growth and productivity (Table 2), as well as in the lowest levels of ammonia at the end of phase II (Table 1). The compost with $2 \% \mathrm{~N}_{\text {initial }}$, besides showing lower productivity, resulted in a mycelial growth approximately $38 \%$ slower than that one obtained on the treatment with
$1 \%$ nitrogen. Thus, even if mushroom producers consider a $10 \%$ productivity to be good, the fact that this compost is colonized slowly means a delay in obtaining a colonized compost. In this context, T1 treatment $\left(1 \% \mathrm{~N}_{\text {initial }}\right)$ would be ideal, as it resulted in the same level of productivity as T2 $(1.5 \%)$, but with a higher mycelial growth. Cavalcante et al. (2008) observed a productivity lower than $10 \%$ and biological efficiency lower than $26 \%$ in the cultivation of $A$. blazei in a compost with an initial $\mathrm{C} / \mathrm{N}$ ratio of 25/1 in three different types of casing soils.

The chemical analysis of $A$. brasiliensis dry mushrooms (Table 3 ) revealed that differences in protein, fat and ash content between the treatments were not significant. On the other hand, significant differences in fiber (source of $\beta$-glucan) and sugar content were observed between the treatments. Nitrogen concentrations of $1.5 \%$ and $2 \%$ $\mathrm{N}_{\text {initial }}$ resulted in the highest fiber content at 6.3 and $6.2 \%$, respectively.

Considering velocity of compost colonization, productivity and biological efficiency, an initial nitrogen concentration between $1 \%$ and $1.5 \%$ must be used to optimize composting for the cultivation of $A$. brasiliensis. When considering also the fiber content, the treatment with $1.5 \% \mathrm{~N}_{\text {initial }}$ should be considered ideal.

\section{ACKNOWLEDGEMENTS}

To FAPEMIG, CAPES and CNPq for their financial support.

\section{REFERENCES}

ANDRADE MCN; KOPYTOWSKI-FILHO J; MINHONI MTA; COUTINHO LN; FIGUEIREDO MB. 2007. Productivity, biological efficiency, and number of Agaricus blazei mushrooms grown in compost in the presence of Trichoderma sp. and Chaetomium olivacearum contaminants. Brazilian Journal Microbiology 38: 243-247.

ASSOCIATION OF OFFICIAL ANALYTICAL CHEMISTS - AOAC. 1990. Official methods of analysis. $15^{\text {th }} \mathrm{ed}$. Washington: AOAC. $1298 \mathrm{p}$.

BURROWS SS. 1951. The chemistry of mushroom composts. Journal Science Food Agricutural 2: 403-410.

CAVALCANTE JLR; GOMES VFF; KOPYTOWSKI-FILHO J; MINHONI MTA,
ANDRADE MCN. 2008. Cultivo de Agaricus blazei na área de proteção ambiental da região de Baturité, em três tipos de camada de cobertura. Acta Scientiarum._Agronomy 30: 513-517.

CHANG ST; MILES PG. 2004. Mushrooms: cultivation, nutritional value, medicinal effect, and environmental impact. Boca Raton: CRC Press. 480p.

DIAS ES. 2010. Mushroom cultivation in Brazil:challenges and potential for growth. Ciencia \& Agrotecnologia 34: 795-803.

EIRA AF. 2003. Cultivo do cogumelo medicinal Agaricus blazei (Murrill) SS Heinemann ou Agaricus brasiliensis (Wasser et al.). Viçosa, Aprenda Fácil, 398p.

FERREIRA FA. 2000. Sistema SISVAR para análises estatísticas. Lavras: UFLA. Available at: www.dex.ufla.br/index.php. Accessed on January 15, 2009.

FLEGG PB; SPENCER DM; WOOD DA. 1985. The biology and technology of the cultivated mushroom. Chichester: John Wiley and Sons. $177 \mathrm{p}$.

FLETCHER JT; GAZE RH. 2008. Mushroom Pest and Disease Control: A Color Handbook. London: Academic Press. 195p.

GONZÁLEZ-MATUTE R; RINKER DL. 2006. Compatibility of ammonia suppressants used in poultry litter with mushroom compost preparation and production. Bioresource Technology 97: 1679-1686.

INSTITUTO ADOLFO LUTZ. 1985. Normas analiticas, métodos químicos e fisicos para análise de alimentos. $3^{\mathrm{a}}$ ed. São Paulo: Instituto Adolfo Lutz, v1. 533 p.

KIEHL EJ. 1985. Fertilizantes orgânicos. São Paulo: Ceres. 492p.

MILES PG; CHANG ST. 1997. Biologia de las setas: fundamentos básicos y acontecimientos actuales. Hong Kong: World Scientific. 13 p.

NELSON N. 1944. A photometric adaptation of Somogyi method for the determination of glucose. The Journal of Biological Chemistry 135: 136-175.

NOBLE R; GAZE RH. 1995. Preparation of mushroom (Agaricus bisporus) composts in controlled environments: factors influencing compost bulk density and productivity. Horticulture Research International 1: 93-100.

OEI P. 2003. Mushroom cultivation - Appropriate technology for mushroom growers. $3^{\text {rd }}$ ed. Leiden: Backhuys Publishers. 429p.

ROSS RC; HARRIS PJ. 1983. An investigation into the selective nature of mushroom compost. Scientia Horticulturae 19: 55-64.

SÁNCHEZ C. 2004. Modern aspects of mushroom culture technology. Applied Microbiology and Biotechnology 64: 756-762.

SHARMA HSS; LYONS G; CHAMBERS J. 2000. Comparison of the changes in mushroom (Agaricus bisporus) compost during windrow and bunker stages of phase I and II. Annals Applied Biology 13: 659-668.

STÖLZER S; GRABBLE K. 1991. Mechanisms of substrate selectivity in the cultivation of edible fungi. In: MAHERMJ. (Ed.). Science and cultivation of edible fungi. Rotterdam: Balkema 1: 141-146.

VAN GRIENSVEN LJLD. 1988. The cultivation of mushrooms. Darlington Mushroom Laboratories Ltda. 515p. 